\title{
Alaskanhuskyjen seerumin E-vitamiini- ja retinolipitoisuus valmennuskauden aikana
}

\author{
Riitta Kempe ${ }^{1)}$, Markku Saastamoinen ${ }^{1)}$ ja Päivi Volanto ${ }^{2)}$ \\ ${ }^{1)}$ MTT Maa- ja elintarviketalouden tutkimuskeskus, Kotieläintuotannon tutkimus, Hevostalous, \\ Varsanojantie 63,32100Ypäjä, riitta.kempe@mtt.fi \\ ${ }^{2)}$ Päivi Volanto, Rehuraisio Oy, PL 101, 21201 Raisio, paivi.volanto@raisiogroup.com
}

\begin{abstract}
Johdanto
Raskasta työtä tekeville koirille suunnatut kuivaruuat sisältävät runsaasti rasvaa (yli 20 \% KA). Tällainen kuivaruoka tulisi säilyttää viileässä ja pimeässä tilassa, jotta ruuan rasvat eivät hapetu ja härskiinny. Lipidien hydroperoksidit ja niiden hajoamistuotteet voivat edelleen hapettaa ruuan muita molekyylejä, kuten entsyymejä, aminohappoja tai DNA:ta, jolloin peroksidien oksidatiivinen vaikutus laajenee (Adams 1994). Härskiintynyt rasva vähentää eläinten ruuan maittavuutta ja syöntiä sekä rasvojen sulavuutta (Borsting et al. 1994). Härskiintynyt rasva katalysoi myös ruuan E-vitamiinin tuhoutumista. Työkoirille suunnitelluissa kuivaruuissa on muun muassa tämän vuoksi huomattavasti ylläpitotasoa korkeampi E-vitamiinipitoisuus. Kuivaruuan E-vitamiinipitoisuuden säilyvyyttä useita kuukausia kestävän varastoinnin aikana tai työkoirien E-vitamiinin tarvetta valmennus- ja kilpailukauden ei kuitenkaan ole vielä riittävästi tutkittu. Raskaan urheilusuorituksen aiheuttaman stressin vaikutuksesta muodostuu peroksideja ja vapaita radikaaleja, jotka voivat vahingoittaa mitokondrioiden kalvoja, solulimakalvostoja ja sarkoplasmakalvostoja (Grandjean 1993). Solukalvot sisältävät monityydyttymättömiä rasvahappoja, joiden hapettuminen ja vahingoittuminen voidaan estää ennen kaikkea riittävän Evitamiinin ja seleenin saannin avulla. E-vitamiini ja seleeni suojaavat kalvostoja erityisesti lihassoluissa. E-vitamiinin käyttö kilpakoirilla perustuu sen antioksidanttisiin vaikutuksiin kudoksissa (luurankolihakset ja sydänlihas), suorituskyvyn kliinisesti mitattavaan paranemiseen ja lihasten kestävyysominaisuuksien paranemiseen (Grandjean et al. 1998). Sekä retinoli että $\beta$-karoteeni pystyvät myös toimimaan antioksidantteina. Plasman retinolipitoisuuden on todettu laskevan rekikoirilla pitkäkestoisen rasituksen aikana (Piercy et al. 2000). Lisäksi tutkimuksissa on todettu $\alpha$-tokoferolia, $\beta$-karoteenia ja luteniinia sisältävän antioksidanttilisäyksen vähentävän rasituksen aiheuttamia oksidatiivisia vaurioita rekikoirilla (Baskin et al. 2000).

Toisin kuin muilla lajeilla, ruuan A-vitamiinipitoisuus vaikuttaa lihansyöjien veren Avitamiinipitoisuuteen ja koiran veren A-vitamiinipitoisuuden perusteella voidaankin arvioida Avitamiinin saannin riittävyyttä (Basset et al. 1984, Wilson et al 1987, Schweigert et al. 1990). Koirat ja ketut pystyvät erittämään jopa $60 \%$ päivittäisestä A-vitamiiniannoksestaan virtsaan. Tämä saattaa olla yksi selitys sille, miksi näiden eläinten veren A-vitamiinipitoisuus voi olla korkea ilman toksisia vaikutuksia (Schweigert et al. 1991). Koirat sietävät jopa 50-kertaisia A-vitamiinitasoja ilman myrkytysoireita (NRC 1985, Golby et al. 1996).
\end{abstract}

\section{Aineisto ja menetelmät}

Tämän kokeen tarkoituksena oli selvittää rekikoirien ruokinnassa käytetyn kuivaruuan E- ja Avitamiinien riittävyys urheilevan koiran tarpeisiin valmennus- ja kilpailukauden aikana. Kuivaruuasta määritettiin E- ja A-vitamiinipitoisuudet säännöllisin väliajoin puolentoista vuoden ajan, jolloin pystyttiin seuraamaan koirien E- ja A-vitamiinin saantia ja vitamiinien hävikkiä säilytyksen aikana. Kuivaruokaa säilytettiin puolentoista vuoden ajan vanhan kaupparakennuksen kylmävarastossa, jonka keskilämpötila oli noin $+5^{\circ} \mathrm{C}$. Verinäytteiden avulla seurattiin ruokinnan ja valmennuksen vaikutuksia koirien seerumin E-vitamiini- ja retinolipitoisuuteen, perusverenkuvaan ja koirien terveydentilaan. Koe tehtiin jatkuvatyyppisenä ryhmäkokeena. Seurantaryhmä muodostui kuudesta alaskanhuskynaaraasta, jotka olivat täyssisaria keskenään. Seurantajakson dieetti muodostui työkoirille suunnitellusta ekstruder-käsitellystä koerehusta (kuiva-ainepitoisuus 96,4 \%, raakavalkuaispitoisuus 36,1 \%, raakarasvapitoisuus $28,6 \%$, raakakuitupitoisuus $1,97 \%$ ja tuhkapitoisuus $8,9 \%$ kuiva-aineessa), jossa oli normaalia aktiivisen koiran rehua korkeammat E- ja A-vitamiinipitoisuudet. Lisäksi vaativaan keskipitkien matkojen rekikoirakilpailuun valmistauduttaessa dieettiin tehtiin 21 päivän ajan $500 \mathrm{mg}: \mathrm{n}$ koirakohtainen E-vitamiinilisäys päivässä. Koirien laskennallinen 

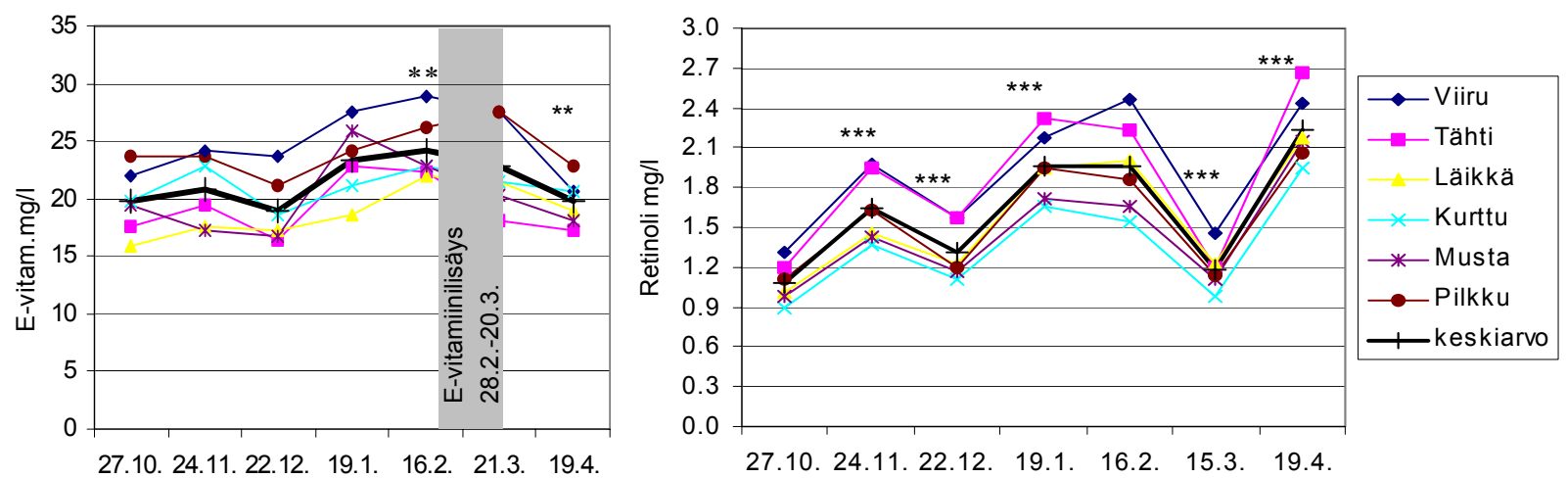

Kuva 1. Alaskanhuskyjen seerumin E-vitamiini- ja retinolipitoisuus 27.10.1999-19.4.2000 välisenä aikana.

energian saanti oli alimmillaan koirien ollessa levossa, 6.6 MJ ME/vrk ja korkeimmillaan raskaimman työjakson jälkeen, 11.3 MJ ME vuorokaudessa. Keskimäärin koirien energian saanti kauden aikana oli 7.9 MJ ME/vrk ( $\mathrm{s} \pm 1.3)$.

Ruuan E- ja A-vitamiinipitoisuuden ja valmennuksen vaikutusta seerumin E-vitamiini- ja retinolipitoisuuteen tutkittiin toistomittausmallilla. Eläin ja jäännöstermi olivat mallissa satunnaistekijöitä ja mittausajankohta kiinteänä tekijänä. Mallissa huomioitiin samasta eläimestä tehtyjen mittausten korreloituneisuus mallittamalla toistomittausten kovarianssirakennetta.

\section{Tulokset ja niiden tarkastelu}

Rehun E-vitamiinista tuhoutui valmistusvaiheessa $39 \%$, mutta tämän jälkeen rehun E-vitamiinipitoisuus, $156 \mathrm{mg} / \mathrm{kg}$, säilyi vakiona 1.5 vuoden säilytyksen ajan. Koirien keskimääräinen Evitamiinin saanti tutkimuksen aikana oli $3 \mathrm{mg}$ E-vitamiinia elopainokiloa kohti vuorokaudessa. Koirien seerumin E-vitamiini-pitoisuus kokeen aikana oli keskimäärin $21.6 \mathrm{mg} / 1( \pm 3.43)$. Alin seerumin Evitamiinipitoisuus oli $15.9 \mathrm{mg} / \mathrm{l}$ ja korkein $28.9 \mathrm{mg} / \mathrm{l}$ (kuva 1). Alaskanhuskyjen seerumin Evitamiinipitoisuudet vastasivat rekikoirilla tehtyjä tutkimuksia, joissa seerumin E-vitamiinipitoisuus on ollut 10-28 mg/l (Reynolds 1994, Grandjean et al. 1998). Ylläpitotasolla olevien koirien Evitamiinin saanti on riittävä, jos niiden seerumin E-vitamiinipitoisuus on 5-8 mg/l (Meyer \& Zentek 1998). Koirien E-vitamiinin saanti tämän kokeen aikana oli riittävä, ja se vastasi kirjallisuudessa rekikoirille annettuja suosituksia. Rekikoirille suositellaan valmennus- ja kilpailukauden aikana 2-3 mg Evitamiinia elopainokiloa kohti vuorokaudessa (NRC 1985, Grandjean 1998, Meyer \& Zentek 1998). Ylläpitotasolla olevan koiran E-vitamiinin tarpeeksi ilmoitetaan 0.5-1 mg elopainokiloa kohti vuorokaudessa.

Kolmen viikon E-vitamiinin lisäysjakson aikana (28.2.-20.3.) koirien keskimääräinen Evitamiinin saanti oli yli 20-kertainen ylläpitotasoon nähden, $23 \mathrm{mg}$ elopainokiloa kohti vuorokaudessa. Koirien seerumin E-vitamiinipitoisuus määritettiin maaliskuussa kaksi viikkoa sen jälkeen, kun Evitamiinilisäykset aloitettiin. Koirien seerumin E-vitamiinipitoisuus laski lievästi $(\mathrm{P}=0.143)$ raskaan kilpailu- ja safarityöskentelyjakson aikana E-vitamiinilisäyksestä huolimatta edelliseen, helmikuun mittaustulokseen verrattuna. Tämän perusteella arvioituna koiriin kohdistui erittäin suuri rasituksen aiheuttama oksidatiivinen stressi, joka selkeästi lisäsi E-vitamiinin kulutusta ja tarvetta. Koirien seerumin E-vitamiinipitoisuus säilyi E-vitamiinilisäyksen $(500 \mathrm{mg} / \mathrm{koira} / \mathrm{vrk})$ ansiosta riittävän korkeana suojaten koiraa ainakin osittain oksidatiivisen stressin vaikutuksilta. Tulokset vastaavat Grandjeanin et al. (1998) tuloksia, jonka mukaansa rekikoirien E-vitamiinin puutostilat voidaan estää lisäämällä koirien ruokaan asteittain, 10-15 päivää ennen raskaan työjakson alkua, 400-500 mg $\alpha$-tokoferolia päivässä. Vaativiin pitkänmatkan kilpailuihin, esim. Iditarod-kilpailuun, valmistautuneiden koirien seerumin E-vitamiinipitoisuuden on tutkimuksissa todettu olevan jopa yli $40 \mathrm{mg} / \mathrm{l}$, ja sen on todettu vaikuttavan positiivisesti koirien suorituskyyn (Hinchcliff et al. 2000). Donoghuen ja Kronfeldin pilottitutkimuksessa (julkaisematon) siperianhuskyjen seerumin E-vitamiinipitoisuudet laskivat kilpailukauden aikana arvoon $9 \mathrm{mg} / \mathrm{l}$, kun se ennen valmennuskauden alkua oli keskimäärin 16 mg/l. Näin merkittävä rasituksen luoma stressi ja seerumin E-vitamiinipitoisuuden lasku näkyivät myös siperianhuskyjen suorituskyvyn heikkenemisenä. 
Kuivaruuan A-vitamiinista tuhoutui valmistusvaiheessa $35 \%$. Kuivaruuan A-vitamiinipitoisuus oli valmistumisen jälkeen $16600 \mathrm{KY} / \mathrm{kg}, 6 \mathrm{kk}$ :n jälkeen $14000 \mathrm{KY} / \mathrm{kg}$ ja yli vuoden säilytyksen jälkeen keskimäärin $12000 \mathrm{KY} / \mathrm{kg}$. Kaiken kaikkiaan A-vitamiinista tuhoutui noin $28 \% 18$ kuukauden säilytyksen aikana. Työkoirille suunnitellun rehun A-vitamiinipitoisuus $14000 \mathrm{KY} / \mathrm{kg}$ oli riittävä rekikoirien tarpeisiin nähden.

Koirien seerumin keskimääräinen retinolipitoisuus lokakuussa, ennen koeruokinnan alkua 1.08 $\mathrm{mg} / \mathrm{l}$ ( \pm 0.16 ) (kuva 1). Seurantajakson (marras-huhti) aikana seerumin retinolipitoisuus oli keskimäärin $1.72 \mathrm{mg} / 1$ (s \pm 0.45$)$. Seerumin alin retinolipitoisuus oli $0.89 \mathrm{mg} / 1$ ja korkein $2.66 \mathrm{mg} / 1$. Koerehuun siirtymisen jälkeen koirien seerumin retinolipitoisuus nousi marraskuussa tilastollisesti erittäin merkitsevästi $(\mathrm{P}<0.0001)$ lokakuun lähtötasosta. Koirien A-vitamiinin saanti nousi ruokinnan vaihtuessa keskimäärin $35 \mathrm{KY}$ :stä $289 \mathrm{KY}$ :öön elopainokiloa kohti vuorokaudessa. Joulukuussa koirien seerumin retinolipitoisuus laski $(\mathrm{P}<0.001)$ intensiivisen harjoittelun seurauksena A-vitamiinin saannin pysyessä vakiona. Tammikuussa koirien seerumin retinolipitoisuus oli jälleen korkea $(\mathrm{P}<0.0001)$, keskimäärin $1.96 \mathrm{mg} / \mathrm{l}$, koska tammikuun näytteenottoa edeltävillä viikoilla (koeviikot 11-12) koirien A-vitamiinin saanti oli vähintäänkin kolminkertainen ylläpitotasoon nähden (338-416 KY/kg/vrk) ja näytteenottoa edeltävät viikot rasituksen osalta kevyitä. Maaliskuun raskaan kilpailu- ja työjakson jälkeen koirien seerumin retinolipitoisuus laski jälleen $(\mathrm{P}<0.0001)$ ollen keskimäärin $1.19 \mathrm{mg} / \mathrm{l}$, vaikka koirien Avitamiinin saanti oli kaksinkertainen (200 KY/ep kg/vrk) ylläpitotasoon nähden. Maaliskuun näytteenoton jälkeen koirat olivat pääasiassa levossa seuraavaan huhtikuun näytteenottokertaan asti ja Avitamiinin saanti oli kaksinkertainen ylläpitotasoon nähden $(216 \mathrm{KY} / \mathrm{ep} \mathrm{kg} / \mathrm{vrk})$. Seerumin retinolipitoisuus nousi tänä aikana tilastollisesti erittäin merkitsevästi $(\mathrm{P}<0.0001)$ arvoon $2.24 \mathrm{mg} / \mathrm{l}$.

Koirien A-vitamiinin saannin katsotaan olevan riittävä, jos seerumin A-vitamiinipitoisuus (retinoli + retinyyliesterit) on keskimäärin 1.42-2.32 mg/l (Meyer \& Zentek 1998). Tässä tutkimuksessa pelkästään seerumin keskimääräinen retinolipitoisuus, jonka osuus on noin $30 \%$ seerumin Avitamiinin kokonaismäärästä (Schweigert 1988), oli em. tasolla eli koirat saivat A-vitamiinia yli todellisen tarpeensa. Koirien seerumin retinolipitoisuudet olivat kuitenkin keskimäärin hieman alemmat kuin Piercyn et al. (2000) tutkimuksessa, jossa rekikoirien seerumin retinolipitoisuudet olivat keskimäärin 2.5-3.5 mg/l. Schweigertin tutkimuksissa koirien plasman retinolipitoisuus oli 0.6-1.5 mg/l, kun plasman A-vitamiinin kokonaispitoisuus aineistossa oli 1.5-4.7 mg/l (Schweigert 1988, 1990). Golbyn et al. (1996) mukaan dieetin A-vitamiinitasot 2000 - $200000 \mathrm{KY} / \mathrm{kg}$ KA ovat turvallisia koirille, mutta yli $400000 \mathrm{KY}$ A-vitamiinia kilossa kuiva-ainetta vaarantavat koiran elimistön kyvyn ylläpitää A-vitamiinin normaalia homeostaasia. Alimmalla A-vitamiinitasolla, $2000 \mathrm{KY} / \mathrm{kg} \mathrm{KA}$, koirien maksan A-vitamiinipitoisuus puolestaan laskee. NRC:n (1985) minimisuositus ruuan Avitamiinipitoisuudeksi on $3336 \mathrm{KY} / \mathrm{kg} \mathrm{KA}$ ja AAFCO:n suositus on $5000 \mathrm{KY} / \mathrm{kg} \mathrm{KA}$. Rekikoirilla voidaan tämän tutkimuksen tulosten perusteella käyttää ruokinnassa kaksinkertaisia A-vitamiinitasoja ylläpitotarpeeseen nähden (200 KY/ep kg/vrk) valmennuskauden aikana, ja kolminkertaisia (300 $\mathrm{KY} / \mathrm{ep} \mathrm{kg} / \mathrm{vrk}$ ) A-vitamiinitasoja intensiivisten rasituksen aikana ilman haittavaikutuksia. Myös Grandjeanin (1989) mukaan rekikoirien A-vitamiinin saanti voi olla kaksinkertainen ylläpitotasoon (75-100 IU/ep kg/vrk) nähden.

\section{Johtopäätökset}

Kuivaruuan valmistusvaiheessa tuhoutuu merkittävä määrä (35-40\%) rasvaliukoisia vitamiineja, mikä on otettava huomioon kuivaruokia suunniteltaessa ja valmistettaessa. Tässä tutkimuksessa kuivaruuan E- ja A-vitamiinipitoisuudet säilyivät hyvin pitkän säilytyksen ajan, vaikka A-vitamiinipitoisuudessa tapahtuikin lievää laskua. Kuivaruuan vitamiinien pitoisuudet olivat riittävän korkeat rekikoiran perusvalmennuskauden tarpeisiin nähden.

Seerumin E-vitamiinipitoisuuden muutokset liittyivät kiinteästi E-vitamiinin saannissa ja rasituksen intensiteetissä tapahtuneisiin muutoksiin. Rekikoirien E-vitamiinin saannin tulisi olla valmennus- ja kilpailukauden aikana keskimäärin kolminkertainen ylläpitotasoon nähden. Koirien Evitamiinin saantia voidaan ja tulisi lisätä tilapäisesti, jos raskas liikuntasuoritus aiheuttaa koiralle voimakasta biologista stressiä, joka selkeästi lisää E-vitamiinin ja mahdollisesti myös muiden antioksidanttien tarvetta. Lisääntynyt E-vitamiinin tarve voidaan täyttää, joko kuivaruuan Evitamiinipitoisuutta nostamalla ja/tai erillisen E-vitamiinilisäyksen avulla. Mikäli koiran seerumin Evitamiinipitoisuus halutaan nostaa vielä korkeammalle tasolle kuin tässä tutkimuksessa (yli $40 \mathrm{mg} / \mathrm{l}$ ), E-vitamiinilisäyksen suuruuden on oltava 500-1000 mg vuorokaudessa. Seerumin korkea Evitamiinipitoisuus vähentää rasituksen aiheuttamia hapettumisvaurioita, parantaa suorituskykyä ja 
palautumista vaativan kilpailun aikana. E-vitamiinin tilapäiseen yliannostukseen ei liity koiralla kliinisiä oireita, ja koirat sietävät hyvin dieetin korkeitakin E-vitamiinitasoja.

Myös seerumin retinolipitoisuuden muutokset heijastelivat kiinteästi liikunnan määrässä ja intensiteetissä tapahtuneita muutoksia, mutta koiran A-vitamiinin tarve ei kuitenkaan lisäänny yhtä dramaattisesti intensiivisen liikuntasuorituksen vaikutuksesta kuin E-vitamiinin tarve. Työkoirille suunnitellun rehun A-vitamiinipitoisuus tulisi optimoida entistä tarkemmin vastaamaan koiran tarvetta. Rekikoirien A-vitamiinin saannin on mieluummin oltava valmennus- ja kilpailukauden aikana optimialueella kuin lähellä minimi- tai maksimisaantia ("safe limit"). Rekikoirilla voidaan kuitenkin tämän tutkimuksen tulosten perusteella käyttää ruokinnassa kaksinkertaisia A-vitamiinitasoja ylläpitotarpeeseen nähden valmennuskauden aikana, ja kolminkertaisia A-vitamiinitasoja intensiivisten rasituksen aikana ilman, että elimistön A-vitamiinin homeostaasin säätelymekanismi vaarantuisi koirilla käytetyillä annostasoilla.

\section{Kirjallisuus}

Adams, C.A. 1994. The role of antioxidants in maintaining fat quality. International animal nutrition symposium: updating the use of animal by-products in animal feeds. National Renderers Association Inc (NRA), London, UK. The proceedings, Utrecht, Netherlands 1994: 51-57.

Bassett, C.F., Loosli, J.K. \& Wilke. F. 1948. The vitamin A requirement for growth of foxes and minks as influenced by ascorbic acid and potatoes. J. Nutr. 35: 629-638.

Baskin, C.R., Hinchcliff, K.W., DiSilvestro, R.A., Reinhart, G.A., Hayek, M.G., Chew, B.P., Burr, J.R. \& Swenson, R.A. 2000. Effects of dietary antioxidant supplementation on oxidative damage and resistance to oxidative damage during prolonged exercise in sled dogs. Am J Vet Res. 61(8): 886-891.

Borsting, C.F., Engberg, R.M., Jakobsen, K., Jensen, S.K., Andersen, J.O. 1994. Inclusion of oxidized fish oil in mink diets. 1. The influence on nutrient digestibility and fatty-acid accumulation in tissues. Journal of Animal Physiology and Animal Nutrition 72: 2-3, 132-145.

Goldby, G.G., Burr, J.R., Longardner, C.N., Hirakawa, D.A.S. \&Norton, S.A. 1996. Effects of measured doses of vitamin A fed to healthy beagle dogs for 26 weeks. Veterinary clinical nutrition 2: 42-49.

Grandjean, D. 1993. Nutrition of racing and working dogs. Part II. Determination of energy requirements and the nutritional impact of stress. Compedium on continuing education for the practicing veterinarian 15 (1): 4557.

Grandjean, D. 1998. Nutrition for Sled Dogs. In: Bloomberg, M.S., Dee, J.F. \& Taylor, R.A. (eds.) Canine Sports Medicine and Surgery. USA. WB. Saunders Company. p. 336-348.

Grandjean, D., Sergheraert, R., Valette, J.P., \& Driss, F. 1998. Biological and nutritional consequences of work at high altitude in search and rescue dogs: The Scientific Expedition Chiens des Cimes-Licancabur 1996. J. Nutr. 128: 2694S-2697S.

Hinchcliff, K.W., Piercy, R.J., Baskin, C.R., DiSilvestro, R.A., Reinhart, G.A., Hayek, M.G. \& Chew, B.P. 2000. Oxidant stress, oxidant damage, and antioxidants: Review and studies in Alaskan sled dogs. In: Reinhart, G.A. \& Carey, D.P. (eds.) Recent advances in canine and feline nutrition: Proceedings of the 2000 IAMS International Nutrition Symposium. Wilmington, USA. Orange Frazer Press. p. 207-218.

Meyer, H. \& Zentek, J. 1998. Ernährung des Hundes: Grundlagen, Füttergrung, Diätetik. $3^{\text {rd }}$ ed. Berlin/Wien. Blackwell Wissenschafts-Verlag. p. 314.

NRC 1985. National Research Council. Nutrient Requirements of Dogs. Nutrient Requirements of Domestic Animals. Revised Edition. National Academy Press. Washington, DC. p. 76.

Piercy, R.J., Hinchcliff, K.W., DiSilvestro, R.A., Reinhart, G.A., Baskin, C.R., Hayek, M.G., Burr, J.R. \& Swenson, R.A. 2000. Effect of dietary supplements containing antioxidants on attenuation of muscle damage in exercising sled dogs. American Journal of Veterinary Research 61: 11, 1438-1445.

Reynolds, A.J., Fuhrer, L., Dunlap, H.L., Finke, M.D. \& Kallfelz, F.A. 1994. Lipid metabolite responses to diet and training in sled dogs. J. Nutr. 124: 2754S-2759S.

Schweigert, F.J. 1988. Insensitivity of dogs to the effects of non-specific bound vitamin A in plasma. Int. J. Vitam. Nutr. Res. 58, p. 23-25.

Schweigert, F.J., Ryder, O.A., Rambeck, W.A. and Zucker, H. 1990. The majority of vitamin A is transported as retinyl esters in the blood of most carnivores. Comp. Biochem. Physiol. 4, p. 573-578.

Schweigert, F.J., Thomann, E. and Zucker, H. 1991. Vitamin A in the urine of carnivores. Int. J. Vit. Nutr. Res. 61, p. 110-113.

Wilson, D.E., Hejazi, J., Elstad, N.L., Chan, I.-F., Gleeson, J.M. \& Iverius, P.-H. 1987. Novel aspects of vitamin A metabolism in the dog: distribution of lipoprotein retinyl esters in vitamin A-deprived and cholesterolfed animals. Biochim. Biophys. Acta 922: 247-258. 